\title{
LEGAL COMPONENT OF THE CONCEPT OF PROVISION OF PUBLIC SERVICES
}

\author{
Eleonora Skyba', Maryna Polishchuk ${ }^{2}$
}

\begin{abstract}
The paper defines the main theoretical aspects of the concept of public services in Ukraine. It is substantiated the expediency of the development of a unified concept of public services as a basic document for the modern domestic rule-making process aimed at developing modern legislation on public services, which is perfect in content and effective in application, and also for the elaboration of its scientific basis - the provisions of modern national administrative-legal science. It is developed a version of the Concept of public services, its content is covered. The proposed version contains three sections: Section I "General provisions" defines the main conceptual framework, raises problems, establishes purpose, tasks, terms of implementation of the Concept of public services; Section II "Ways and methods of problems solving, terms of implementation of the Concept of public services in Ukraine" specifies particular measures that must be taken to achieve the goal and solve the problems. These measures are conditionally divided into three groups: educational measures (the process of preparation of the standards for legal education), scientific measures (research), law-making measures (statutory acts regulating the activities of actors, procedures, guarantees). Section III "Expected results of the implementation of the Concept of public services in Ukraine" proposes the main results predicted to be achieved by virtue of three abovementioned directions (groups of measures) for the implementation of the Concept's provisions.
\end{abstract}

Key words: responsibility, electronic public service, control, public services, provision of public services, public services system, appeals against decisions, acts or inactivity of public authorities for provision of public services.

JEL Classification: E44, H10, K10, K13

\section{Introduction}

The problem statement is to build a democratic Ukraine of European standard and it should not be based solely on discussing the problems but it requires radical changes in the legal field, where a person, his/her rights and freedoms must become a priority.

Adoption of the Concept of public services in Ukraine should contribute to the formation, improvement and further development of the system of provision of public services on the basis of clearly defined legal principles. It will enable to meet the needs of citizens-consumers of public services and will ensure the protection of their rights and interests, which are guaranteed by the Constitution of Ukraine and other regulatory acts.

The current state of the provision of public services in Ukraine is characterized by a large number of shortcomings and problems despite the fact that the state must guarantee the right of every consumer to an impartial and fair decision concerning a case solution within a reasonable time.

Now, issues of public services in Ukraine require thorough research. So, feedback is important - thoughts,

\footnotetext{
Corresponding author:

${ }^{1}$ Dnipropetrovsk State University of Internal Affairs, Ukraine.

E-mail: skyba eleonora@i.ua

${ }^{2}$ Dnipropetrovsk State University of Internal Affairs, Ukraine.

E-mail: miraslava13.07@gmail.com
}

reactions, assessments of citizens about the essence of reforms and, in particular, their effectiveness.

Analysis of the latest researches and papers on a research topic. The issues of legal regulation of services as a legal category are the focus of scholars, and their various aspects were studied in scientific papers of such scholars as V. B. Averianov, K. K. Afanasiev, V. T. Bilous, I. P. Holosnichenko, N. L. Huberska, S. L. Dembitska, S. V. Kivalov, I. V. Kovbas, I. B. Koliushko, T. O. Kolomoiets (Kolomoiets, Pyrizhkova, Armash etc., 2009; Kolomoiets, 2002), V. K. Kolpakov, A. T. Komziuk, S. F. Konstantinov, R. S. Melnyk, S. H. Stetsenko, V. P. Tymoshchuk (Tymoshchuk, 2003), and others.

It also should be noted that for the first time, only thesis research of O. M. Bukhanevych is defended at the level of doctoral dissertation "Theoretical and legal and praxeological principles of provision of administrative services in Ukraine” (Bukhanevych, 2016), in which the theoretical foundations and practice of legal regulation of administrative services provision in Ukraine are comprehensively disclosed. 
The purpose of the paper is to propose the concept of the provision of public services in Ukraine on the basis of a comprehensive analysis of available scientific and regulatory sources.

\section{Results of sociological research (residents of Dnipropetrovsk, Zaporizhzhia, Kyiv, Lviv, Odesa, and Kharkiv region)}

Presentation of the main material. The study of citizens' opinion concerning this issue was carried out by the method of questionnaire survey by applying a nonrandom method of respondents' selection (residents of Dnipropetrovsk, Zaporizhzhia, Kyiv, Lviv, Odesa, and Kharkiv region) - a sample of the population of 18 years old is available. In total, 450 respondents were interviewed.

The list of the main shortcomings in the system of provision of public services was sufficiently detailed. In the opinion of the respondents, the main problem is in obliging citizens to collect certificates and other documents - more than half of respondents expressed this opinion $-44.7 \%$. The list of problems also involves (in descending degree) the attitude to citizens as to requesters, disrespect for them - 34.2\%; burdensome bureaucratic procedure for obtaining public services - 32.9\%; demand of certificates and other documents from citizens, submission of which is not required by the legislation - $31.3 \%$; unreasonably long or even indefinite term of provision of certain services $27.7 \%$; unreasonable requirement for citizens to receive related paid services - $25.8 \%$; unjustified partition (cutting) of one service for several paid services and improper professional training of officers providing services, especially it touches psychological aspects of communication with citizens $-23.1 \%$. These are the eight main complaints of citizens against the system of public services. Attention is also paid to the imperfection of the current legislation, which not only complicates control over the system but also improperly regulates the procedure for the provision of services. Citizens negatively responded about the necessity to appeal to several bodies for resolving issues. It should be noted that there were also such respondents who pointed to the territorial "dispersion" of different authorities and their units, and it creates additional difficulties in finding the necessary structure and promotes the unjustified introduction of new types of services.

Regarding the types of feedback that must be used by the authorities in order to improve the quality of public services, the largest number of responses was in favour of the book of complaints and proposals, which should be placed in an accessible place for visitors $44.7 \%$ of respondents (as it was in Soviet times), or the use of hotline $-44 \%$ of respondents consider this type of communication as one of the most successful and effective, while $25.8 \%$ think that, if it is necessary, citizens can appeal to the public reception office as a body that will provide feedback. The role of modern information channels in establishing feedback, as well as the role of the mass media, is small (it was noted by almost 22\%), but it still needs attention.

The aspect as a reduction of the number of documents required for the reception of a service occupies a significant place among the measures for improving the quality of public services $-80.4 \%$ of respondents emphasize the need to solve this problem as the system of providing services in our country, especially in respect of the execution of any document, is characterized by excessive bureaucratization. In this context, the process of using electronic document circulation and its establishing into the work of the authorities under the principle of "one-stop shop" plays an important role almost half of the respondents (44\%) pay attention to the necessity of introducing such forms of work. Emphasis is also placed on the introduction of new modern forms of work through the Internet - 32.9\%; an increase of responsibility of civil servants for poorquality of service provision - $28.7 \%$; improvement of the technical quality during providing services $-27.7 \%$.

Among 63.9\% of respondents who needed certain services, $17.3 \%$ were dealing with registration, $14.9 \%$ were receiving permits, and $10.9 \%$ were receiving licenses and other services. Also, $49.6 \%$ of respondents answered the open question regarding names of institutions, which were being visited by citizens during the year. The units subordinated to the Ministry of Justice of Ukraine (state registrars, notaries) are leaders in terms of appeals $-2.8 \%$ indicated this structure; the same number of visitors was recorded in the housing and municipal bodies. City councils and district executive committees are second in terms of visitors $2.1 \%$, land resources management services are third $1.8 \%$. Those respondents who have applied for public services but have not indicated the name of a structure may not remember it or, which is most likely, do not want or are afraid to indicate it. It should be noted that some of the interviewees pointed agencies that are not related to the procedure of providing public services, such as city hospitals, public educational institutions, etc. Thus, there is a problem as the lack of the necessary amount of information about the structures, which provide public services, and which provide services. It can be assumed that those respondents who answered that they absolutely know nothing about providing the population with public services for by executive authorities and local self-government bodies gave such answers to the questions. We even indicate that at the front of a questionnaire, there was information note, which stated that public services did not include control activities (controlling, auditing, inspections, etc.), economic, educational, and medical services.

The frequency of appeals of citizens to the authorities varies from 2 to 4 times $-34.9 \%$, that is, a one-time visit 
to the government does not mean that an issue will be solved, and most likely, problems may be settled only through a long-term visiting of agencies. Herewith, $18.7 \%$ were able to resolve their issues by visiting the necessary agency at once. Also, $4.3 \%$ indicated that they appealed to the necessary bodies 5-10 times, but these were the respondents who pointed to several authorities.

Those $63.9 \%$ of respondents, who were appealing to the authorities during the year, assessed some of the components of the work of executive bodies' representatives. Thus, the respondents showed the highest level of satisfaction with the availability of paper documents and forms $-16.4 \%$; the competence of employees - $14.2 \%$ and the schedule of the authority - $10.9 \%$. Respondents who are partially satisfied with the competence of employees - $28.7 \%$; general condition of the premises - $24 \%$; informative content of boards at the entrance to the premises and the presence of other indicators $-21.3 \%$; affability and kindness of the workers - 20.9\%. Moreover, $21.8 \%$ of respondents are dissatisfied with the conditions for access and movement of handicapped persons, the arrangement of places for waiting and filling of documents $-21.8 \%$, informative content of boards at the entrance to the premises and availability of other indicators $-21.6 \%$, convenience of services payment $17.6 \%$. If we use the data that represents the sum of the indicators of the scale "satisfied", "partially satisfied", "partially dissatisfied", and "dissatisfied", the leaders of high appraisal are such indicators as competence of workers $-42.9 \%$, the availability of paper documents and forms - $36.2 \%$, informative content of boards at the entrance to the premises $-27.7 \%$; the leaders of the negative assessment are the conditions for access and movement of handicapped persons - 46.2\%, convenience of services payment $-29.8 \%$; the speed of service delivery - 22.9\%; arrangement of places for waiting and filling of documents $-22.2 \%$.

Respondents were not satisfied with the quality of providing public service $-51.5 \%$ were partially satisfied for various reasons: additional payments were made (18.2\%), additional documents were required (17.3\%), the term of services provision was violated (16\%). Rather more than a tenth of the respondents (11.8\%) indicated that they were quite satisfied, as they received a qualitative service on time.

Among the difficulties, which were faced by citizens when applying for a public service, the following is dominated: long queues to the authorities - 36.2\%; time expenditures - 32.7\%; non-awareness about the required list of documents $-22.7 \%$; the presence of a large number of agencies that must be visited to receive a service - 20.9\%; inconvenient premises in which citizens wait for a personal reception - $22.0 \%$; inquiry telephone wasn't answering a call for a long time during the working day or the connection was missing and the uncomfortable reception schedules of citizens gave the same number $-20.7 \%$. These are the seven main comments of respondents, which need to be resolved by the authorities at both the state and local levels.

Among $61.6 \%$ of public services receivers, $12.2 \%$ of the respondents did not need additional resources and additional actions in solving a problem. Among those who were forced to take other opportunities for a positive solution for their case, $27.1 \%$ incurred unjustified additional financial expenses, $23.1 \%$ engaged influential connections, $22.7 \%$ of respondents claimed that they solved the issue with the help of a bribe, $20.4 \%$ used additional information.

When asked about possible solutions to problems which were faced by citizens during receiving public services, $23.1 \%$ answered that they were using influential connections, $18.9 \%$ complained to higher authorities, and $34 \%$ solved problems with the help of bribe (where $22.4 \%$ - in cash equivalent or in the form of gifts, and $11.6 \%$ - in the form of certain services). Those $18.9 \%$ of citizens who complained to the highest authorities show that not always complaints help to solve problems. Thus, $9.3 \%$ of the respondents indicated that their complaint was rather satisfied, $2.1 \%$ rather were not satisfied with the complaint, and $4.9 \%$ of the citizens were not satisfied with the complaint at all. Only $2.6 \%$ of the respondents were satisfied.

Consequently, all above-mentioned allows us to make the main conclusion. The quality of public services is a set of characteristics of a public service that determines its ability to meet established or expected customer's needs. Unfortunately, the Ukrainian system of public services has significant disadvantages. First, the population does not have the necessary, reliable and, in general, complete information about this process (procedure). Second, citizens do not use all possibilities to receive services in case of such need (for example, all possibilities of the Internet - from a search of the necessary information on the website to online consulting and answers receipt to e-mail). Communication is carried out according to old methods, through personal contacts at the reception, less often - through telephone counselling, via the Internet. Hence, a large number of citizens' complaints, time expenditure, rudeness, and disrespect. The problem of burdensome bureaucratic order of reception of public services, extortion of certificates and other documents from citizens play not the last role. In this area, such type of activity as document circulation will significantly improve the quality of provision of public services. It will, first of all, save time on receiving a service, allow avoiding excessive bureaucracy, and solve the problem of material costs both on the part of the ordinary citizen and the state. Meanwhile, those respondents, who were receiving public services during the year, remain dissatisfied with the quality of this process and try to solve their issues not only by lawful methods but also with the use of additional options from ties to bribes. 
So, highlighted the results of the sociological research on the provision of public services, we will outline the main theoretical provisions of the concept of public services in Ukraine.

Operation of this Concept covers public relations related to the provision of public services in Ukraine.

The terms that are used in this Concept have such definition as follows: a public service is an activity of the public administration bodies, which is regulated by public-law rules relatively satisfaction of the public interest in considering the application of a natural or legal person for the issuance of an administrative act (decision, permission, license, certificate, act, authorization document, registration, etc.), aimed at ensuring his/her rights and legal interests and/or performing statutory obligations by a person through financing with the use of public funds;

the system of public services is a set of elements and the connection between them, which is regulated by publiclaw norms in the activities of public administration bodies in relation to the satisfaction of the public interest in considering the application of a natural or legal person for the issuance of an administrative act (decision, permit, license, certificate, act, certificate, registration, etc.), aimed at ensuring his/her rights and legitimate interests and/or performing statutory obligations by a person through financing with the use of public funds;

a procedure for the provision of public services is the procedure of the activities of public administration, which is regulated by administrative and legal norms, in considering the application of a natural or legal person regarding the implementation of a decision of the authorized body aimed at ensuring its rights and legitimate interests and/or the fulfilment of person's duties specified by the law;

unified state portal of public services is a nationwide automated information system that enables the subjects of the application to receive public services virtually (in electronic form);

electronic public service is a governmental activity of an entity of public administration that is authorized to provide public services, which is implemented through information and communication technologies using an electronic digital signature without direct interaction with the subject of appeal (individual or legal entity) aimed at the acquisition, change or termination of the rights, duties and/or the satisfaction of the legitimate interests of natural or legal persons in accordance with the law, which leads to a certain result that manifests itself in the form of issuance of an administrative act (permission, license, certificate, registration, etc.);

the control of the provision of public services is a form of guarantee of ensuring the legality of public services in Ukraine, which is regulated by the legislation implementing in the activities of subjects of administrative law, including citizens or their associations in relation to the control over the realization of the provisions of regulatory acts, powers and observance of rights, freedoms, and legitimate interests of the subjects of application (natural or legal person) by the subjects of public administration;

appeal against decisions, actions or inaction of the public administration bodies of public services provision is a form of guarantee of assurance of the legality of public services in Ukraine, which is implemented through a normatively regulated procedure for the execution of procedural actions that ensure legal and objective consideration of cases in administrative and/or judicial procedures on appeal against decisions, actions or inactivity of executive bodies and local selfgovernment bodies, their officials and officers regarding the consideration of an application of a natural or legal person on issuance of an administrative act (decision, act or decree on reception of permission, license, registration certificate, identification document, certificate, etc.);

the responsibility of public servants for the provision of public services is a form of guarantee of security of the legality of public services in Ukraine, which is regulated by the legislation, implemented in the activities of the relevant subjects of public administration or court in relation to prosecution for not providing public services or failure to perform the relevant duties by employees/officials of public administration;

the subject of the application is an individual, a legal entity that applies for public services;

the subject of the provision of public service is an executive body, another state body, the authority of the Autonomous Republic of Crimea, a local selfgovernment body, and its officials authorized to provide public services in accordance with regulatory acts; centre for public services provision is an ongoing subdivision of a local state administration or a local self-government body, which provides public services by virtue of an administrator through the interaction with various entities of the public administration for the provision of public services;

quality of the provision of public services is a degree of compliance with the criteria that should be approved at the level of the legislative body in the form of standards for the provision of public services, and violation of which should lead to legal liability of employees of public administration body;

availability of public services is a guarantee of equal conditions for all subjects of appeals (physical or legal person) to receive public service in a specified manner; standards for the provision of public services by public administration bodies are general rules on order of procedure for the acceptance, registration, consideration of applications for public services, rendering of decisions during public administration, deadlines for proceedings, as well as the procedure for charging fees and grounds for liability of authorities, etc. 


\section{Ways and methods of problems solution, implementation terms of the Concept of the provision of public services in Ukraine. Problems, which are covered by the Concept of public services in Ukraine}

An effective, well-organized institute of public services is a key factor in the development of civil society in democratically developed countries. For this reason, the EU way which was chosen by Ukraine requires pivotal changes and reform of the existing system for the provision of public services.

After the issue of Decree of the President of Ukraine "On Measures for the Implementation of Administrative Reform Concept in Ukraine" dated June 22, 1998, No. $810 / 98$, the building of a service, democratic state is the main task, which involves meeting the needs of natural and legal entities, promoting and ensuring the realization of their rights, freedoms, and legitimate interests. One of the state "tools" in this activity is public services, which take one of the main positions in activities of public administration entities.

The basic doctrine of public services is the concept of the state's service to a man and citizen. Now public management of this sphere of social relations creates the necessity to elaborate an effective system for the provision of public services, which will guarantee law enforcement for needs' satisfaction of subjects of appeals (natural or legal person) for certain services with compliance of quality standards and principles of public services performance.

Despite some improvements in the provision of certain types of public services over recent years, it should be noted that the modern mechanism of public services' provision by public administration subjects has significant shortages that shows a clear need for its refinement, that is, the development of new approaches, their approbation in both lawmaking and law-enforcement activities of relevant subjects.

An available system of provision of public systems in Ukraine is characterized by the ambiguity as at legislative as sub-legislative levels, non-transparency, and lack of proper regulation, closed nature for consumers (natural or legal persons), so it needs immediate reforming. For this reason, it is necessary to adopt the Concept of public services provision in Ukraine.

To provide public services, it is essential to resolve problems as follows:

- the lack of legislative consolidation of the concept of public services, the system of public services, types of public services, the mechanism of providing public services;

- the lack of register of public services at the legislative level, which would indicate all types of public services;

- the lack of definition of the concept and types of administrative charge for public services at the legislative level;
- the problem of decentralization of the provision of public services;

- the uncertainty of mechanism for procedure regulation of the provision of public services;

- the problem of legal regulation of public relations in terms of providing public services in an appropriate electronic form;

- the lack of proper regulation of the issue of fee/free-ofcharge basis for public services;

- the problem of legislative definition of the powers of the subjects providing public services, which manifests itself in duplication of functions of executive authorities and local self-government;

- the lack of proper regulation of guarantees types for law enforcement of public services in Ukraine in regulatory legal acts;

- insufficient legislative consolidation of the concept and types of control in the sphere of public services provision;

- the lack of resolution of the issue regarding the procedure for the formation, distribution, and use of budget funds by various entities of public administration on the provision of public services at the legislative level; - the problem of elaborating the issues on criteria and standards for the provision of public services at the legislative level;

- the problem of creation of appropriate material, financial and organizational conditions for the provision of public services by subjects of public administration.

Purpose and tasks of the Concept of public services in Ukraine.

The purpose of the Concept is to organize purposeful activities of subjects of public administration in order to elaborate an effective system and mechanism for public services' provision in Ukraine.

The task of the Concept is to define doctrinal directions for the further development of the system of public services provision.

Ways and methods of problems' solution, implementation terms of the Concept of public services in Ukraine.

In order to achieve the goal and solve the tasks envisaged by this Concept, it is necessary to ensure the implementation of complex measures regarding:

1) adoption of the laws as follows: Administrative and Procedure Code of Ukraine, "On Public Services"; "On List of Public Services and Payment (Administrative Fee) for their Provision"; "On Electronic Trust Services"; "On Local Self-Government Bodies in Ukraine"; "On Public Control" etc.

2) creation of the list of public services provided by the subjects of public administration through developing clear criteria for their grouping (by subject, type, fee, etc.);

3) functional extension of local self-government bodies on the provision of public services with the purpose of decentralization process for the latter; 
4) introduction of public services provision under the principle of "single window system", "single office" for entities of appeal (consumers) in order to visit only one body where the majority of public services would be provided and, consequently, the introduction of an effective mechanism for the protection of human and civil rights and freedoms in practice;

5) development and implementation of criteria for quality assessment of providing public services in the activities of public administration entities;

6 ) delineation of the powers of entities of public administration for the provision of public services to improve the quality of public services provision; elimination of duplication of functions, corresponding collisions in law enforcement activities, etc.;

7) provision of public administration entities with highly qualified specialists, who are called to implement state policy in public services in order to exercise the rights, freedoms, and legitimate interests of individuals and legal entities (consumers), taking into account modern approaches and models of human resources management;

8) establishment of centres for public services' provision by delegating the functions of public administration subjects for the purpose of providing the most popular public services (registration of real estate; drawing-up and issuance or exchange of Ukrainian passport for travelling abroad, etc.) only in these centres;

9) termination of the law-enforcement activities of intermediary subjects in providing public services;

10) examination of an issue and decision on a possibility to delegate certain functions of subjects of public administration on public services' provision to private economic entities;

11) creation of appropriate material, financial, and organizational conditions for the provision of public services by entities of public administration;

12) elaboration of an effective guarantees system for ensuring lawfulness of public services in Ukraine regarding the provision of public services (control over the provision of public services; appeals against decisions, actions or inactivity of public administration bodies on public services, the liability of public servants for the provision of public services);

13) development of specific measures for the introduction of electronic document flow, electronic signature, protection of communication channels for the provision of public services;

14) creation of a unified electronic database ("public services register") regarding the provision of public services by competent authorities.

To resolve the problems impeding the development of public services in electronic forms, it is necessary:

1. to integrate official websites of public administration bodies, allied services with information systems of public services entities providing a single authorization and use of a personal account for users of public services;
2. to approve a list of public services in electronic form, focusing on the services that are typically used by consumers (natural or legal persons), by virtue of statistical data and sociological research, which is a prerequisite for a successful service and democratic state;

3. to develop a Unified State Portal of Public Services at the legislative level as a single mechanism for providing public services in the electronic form and eliminate other websites, which render services;

4. to ensure the availability and openness of public services in electronic form, in particular: to provide public services using mobile means and services; to inform citizens about the benefits and procedure for the provision of public services in electronic form in public places; to perform a periodic TV and radio broadcasting of short information programmes towards the provision of public services in electronic form;

5. to develop and adopt regulatory legal acts which will improve the regulation mechanism of public services in electronic form.

Concept Execution Deadline: 2017-2020.

Expected results of the Concept of public services provision in Ukraine.

The Concept implementation will permit to achieve the following results in the future:

1) to create favourable conditions for the provision of public services to appeal entities;

2) to improve the level of legal consciousness of consumers during public services receiving;

3 ) to provide information openness and activity transparency of entities of public services administration; 4) to reduce the level of corruption risks in the process of providing public services;

5 ) to improve the quality of providing public services;

6) to reduce the financial and time expenses of entities of appeals when receiving public services;

7) to improve the level of consumers awareness (individuals or legal entities) of public services;

8 ) to ensure the effectiveness of guarantees implementation for ensuring the lawfulness of public services in the activities of public administration entities in providing public services;

9) to advance the efficiency of public administration as a result of procedures simplification, reduction of administrative expenditure, application of modern methods for public administration in public services provision etc.

\section{Conclusions}

It was elaborated the Concept of public services in Ukraine, which consists of three main sections (section I "General provisions", section II "Ways and methods of problems solution, implementation terms of the Concept of public services provision in Ukraine", section III "Expected results of the Concept of provision of 
public services in Ukraine"); three main priorities of its implementation are identified - doctrinal, educational, and normative, the practical implementation of which will contribute to the formation of a new modern scientific basis for rulemaking and law enforcement regarding the maximum use of public services resource.

It was proposed the directions for improvement of the provision of public services:

$\checkmark$ reconsideration and reduction of public services in a single register, which would contain the name of public service, the subject of public administration that provides a public service, the regulatory framework for the provision of a particular type of service, a list of documents for receiving a service, a form of payment, etc.;

$\checkmark$ the provision of public services complex to individuals and legal entities in the so-called "single offices" for the purpose of constructing a service state, that is, providing quality services to particular consumers with the minimum percent of attendance of the subject of public administration;

$\checkmark$ balanced division of powers of public administration entities in the provision of public services taking into account the principle of legality, the rule of law, etc., upon the condition of simultaneous adherence to quality criteria for the provision of public services;

$\checkmark$ decentralization of the provision of public services, which envisages that the majority of the abovementioned services should be performed at the level of local selfgovernment bodies and responsible "single centres", "single offices"; $\checkmark$ the development, adoption, and implementation of the criteria for quality assessment of public services in the law-enforcement activity of public administration subjects;

$\checkmark$ provision of public administration entities and established public service centres, such as centres for provision of administrative services, with highly skilled experts, whose aim is to implement public policy in providing public services in order to realize the rights, freedoms, and legitimate interests of entities of appeal taking into account modern approaches and models of public administration;

$\checkmark$ examination and adoption of a decision on the possibility to delegate certain functions of public administration subjects on public services' provision to certain private economic entities in order to ensure competitiveness and improve the quality of services;

$\checkmark$ creation of a control mechanism in providing public services as one of the guarantees of ensuring legality in the process of protecting the rights and freedoms of man and citizen;

$\checkmark$ draft and adoption of regulatory and legal acts on the mechanism for interaction and coordination of public administration subject in the process of providing public services.

The implementation of the above directions will promote the creation of an effective system of public services that will guarantee the protection of human and citizen rights and freedoms, which in turn will contribute to the formation of a service-oriented, democratic state.

\section{References:}

Bukhanevych, O. M. (2016). Teoretyko-pravovi ta prakseolohichni zasady nadannia administratyvnykh posluh $\mathrm{v}$ Ukraini [Theoretical-legal and praxeological principles for the provision of administrative services in Ukraine] (PhD Thesis), Kyiv: Instytut zakonodavstva Verkhovnoi Rady Ukrainy.

Tymoshchuk, V. P. (2003). Administratyvna protsedura ta administratyvni posluhy: zarubizhnyi dosvid i propozytsii dlia Ukrainy [Administrative procedure and administrative services: foreign experience and proposals for Ukraine]. Kyiv: Fakt. (in Ukrainian)

Kolomoiets, T. O., Pyrizhkova, Yu. V., Armash, N. O. etc. (2009). Administratyvne pravo Ukrainy: pidruchnyk [Administrative Law of Ukraine: textbook]. Kyiv: Istyna. (in Ukrainian)

Kolomoiets, T. O. (2002). Upravlinski posluhy v konteksti vzaiemovidnosyn osoby y orhaniv mistsevoi vlady v Ukraini: kontseptualnyi i normatyvnyi aspekty [Management services in the context of relations of a person and local self-government bodies in Ukraine: conceptual and normative aspects]. Aktualni problemy derzhavnoho upravlinnia, 7, 178-182.

Prezydent Ukrainy (1998). Pro zakhody shchodo vprovadzhennia Kontseptsii administratyvnoi reformy v Ukraini: Ukaz Prezydenta Ukrainy vid 22 lypnia 1998 r. № 810/98 [On measures to implement the Concept of administrative reform in Ukraine: Decree of the President of Ukraine dated July 22, 1998 No. 810/98]. Retrieved from: http://zakon4.rada.gov.ua/laws/show/810/98

Kabinet Ministriv Ukrainy (2006). Pro skhvalennia Kontseptsii rozvytku systemy nadannia administratyvnykh posluh orhanamy vykonavchoi vlady: Rozporiadzhennia Kabinetu Ministriv Ukrainy vid 15 liutoho $2006 \mathrm{r}$. № 90 [On approval of the concept for development of the system of administrative services provision by the executive bodies: Order of the Cabinet of Ministers of Ukraine dated February 15, 2006 No. 90]. Retrieved from: http://zakon4.rada.gov.ua/laws/show/90-2006-r

Leheza, Ye. O. (2018). Administrative and legal component of the concept of provision of public services in Ukraine (according to the results of sociological survey). Administrative law and administrative-procedural law: origins, achievements and prospects of development: collective monograph. Riga: Izdevnieciba «Baltija Publishing». (in English)

Leheza, Ye., Dzhafarova, O., Savielieva, M. (2018). Structural and legal analysis of scientific activity regulation in developed countries. Baltic Journal of Economic Studies, 4(3), 147-157. doi: 10.30525/2256-0742/2018-4-3-147-157 